\title{
15 Repositioning the agency of Rastafari in the context of COVID-19 crisis in Zimbabwe and Malawi
}

Fortune Sibanda

\section{Introduction}

Globally, the raging coronavirus (COVID-19) pandemic caused by the SARS-CoV2 virus has created an unprecedented health crisis affecting over 80 million people and claiming over 1,750,000 lives (Kovalchuk, Wang, Li, Rodriguez-Juarez, Ilnytskyy, Kovalchuk, \& Kovalchuk 2021). First detected in Wuhan in China, the World Health Organisation (WHO) declared it a public health emergency on 30 January 2020 (Nhamo, Dube \& Chikodzi 2020:4; WHO 2020). The SARS-CoV2 mainly spreads through humanto-human transmission particularly via airborne and contact routes. Research has shown that "COVID-19 has a rather broad spectrum of clinical manifestations, ranging from asymptomatic, to mild flu-like disease, to pneumonia, that in some cases can further progress to acute respiratory distress syndrome (ARDS), major organ failure and death" (Kovalchuk et al. 2021:1571). In addition, Kovalchuk et al. (2021) observed that approximately $20 \%$ of COVID-19 cases are serious or severe, and death rate is currently estimated to be around $10 \%$. In all this, whilst the elderly and individuals with pre-existing conditions are among the most affected, it has recently become thread-bare that no one is completely safe from the ferocity of the disease across the class, gender, age, race and national divides. This makes COVID-19 pandemic a serious health crisis that requires urgent action by individuals, private and public institutions as well as religious players.

This chapter examines the Nyabinghi Rastafari communities' responses to COVID-19 crisis in Zimbabwe and Malawi. The chapter argues that Rastafari, an often stigmatised, misunderstood, demonised and criminalised minority religious movement located on the margins (Afari 2007; Sibanda 2017a), has navigated around hegemonic attitudes, politricks and conspiracy theories of 'Babylon' system in order to reposition its agency in the context of COVID-19 crisis in both Zimbabwe and Malawi. Rastas consider 'Babylon' to be Western hegemony in general terms, but the term also refers to any system of oppression, both by whites or blacks who are never trusted because they are full of tricks - 'politricks' (Edmonds 2003). In other words, 'Babylon' is life-denying and de-humanising, which has resulted in 
Rastafarians protesting against the endemic Western epistemological hegemonic tendencies detrimental to human flourishing. The Rastafari Afrocentric counter-cultural perspective echoes what the Nigerian literary artist, Chimamanda Ngozi Adichie, described as "the danger of a single story" (Adichie 2009). Therein, it has to be asked: To what extent can Rastafari agency provide an alternative narrative in the context of COVID-19 crisis in Zimbabwe and Malawi? Before delving into the nuts and bolts of these issues, focus is first placed on the theoretical framework and research methodology that informed the study.

\section{Theoretical framework and research methodology}

The chapter was informed by the Afrocentric theoretical framework and a qualitative research methodology. Also known as Afrocentricity, the Afrocentric theory is the study and examination of phenomena from the standpoint of Africans as subjects rather than objects calling for "collective consciousness" among African people (Asante 1998, 2007; Johnson 2001:408). Popularised by Molefi Kete Asante and a group of other Temple University scholars, Afrocentricity regards history, culture and philosophy of African people as critical in determining one's approach to reality and the understanding of the world. Put differently, Afrocentricity implies that there is a distinct African worldview anchored on three basic tenets, namely, (a) harmony with nature, which emphasises the uniqueness and right-to-be of every group and species; (b) survival of the tribe, which suggests a reciprocal relationship between the individual and the community; (c) and foremost, spiritual conscientiousness, which reveals that the spirit is invested in everything (Johnson 2001:409; Setiloane 1986:4). These tenets are said to be expressed in the thoughts and behaviours of most African people and could therefore inform their responses to emergency disaster situations such as COVID-19. The broader intellectual aim of Afrocentricity is to challenge and to deconstruct Western denial and misrepresentation of African history, knowledge systems and culture (Asante 1998; Sibanda 2017b:191), which could foreground the agency of Rastafari.

With Rastafari being an Afrocentric movement in its orientation, the Afrocentric theory is helpful in exploring Rastafari responses to COVID-19 pandemic in Zimbabwe and Malawi. The Afrocentric theory is beneficial because it can stand as "both a corrective and a critique" (Asante 2007:27) to the attitudes and actions of current and future generations pertaining to the coronavirus disease. The corrective features of the Afrocentric theory targets the stigmatised, exploited, underutilised, underdeveloped, misused and abused Rastafari lifestyle, philosophy and spirituality that could be harnessed to combat COVID-19 crisis in Zimbabwe and Malawi. As a critique, the Afrocentric theory could challenge Africans to express their agency seeking home-grown solutions tailored to the public health needs and predicaments of Zimbabwe, Malawi and the African continent at large. 
Afrocentricity challenges the white "racial superiority" that places Western culture at the centre, whilst African heritages are marginalised. This explains why Asante and other scholars developed Afrocentricity in order to "obliterate the mental, physical, cultural and economic dislocation of African people by thrusting African people as centred, healthy human beings in the context of African thought" (Asante 2007:120). Therefore, the Afrocentric theory is relevant to this study as it challenges the politricks of Western epistemology and racism by placing the agency and action of African people at the centre in the fight against COVID-19 pandemic in Zimbabwe and Malawi.

The chapter utilised a qualitative phenomenological research design that provided a description of the experiences of participants from an insider perspective. The study corroborated insights from the phenomenological and historical approaches to describe and analyse data. The historical method involves a hermeneutics and is important in tracing the origins, development and impact of the COVID-19 pandemic and to bring out how Rastafari communities perceived the disease in Zimbabwe and Malawi. The research used the phenomenological principles such as epoche (bracketing out), descriptive accuracy, eidetic intuition (establishing the meaning) and comparison (Cox 1996; Sibanda 2017b:192). The two approaches were used in a complimentary way. In order to collect data, the study conducted unstructured in-depth telephonic interviews with 14 purposively sampled information-rich Nyahbinghi Rastafari elders in Zimbabwe and Malawi. Of the 14 interviewees, nine of them were based in Zimbabwe whilst the remaining five were based in Malawi. In Zimbabwe, of the nine study participants, two were women Rastas and seven were male whereas in Malawi one participant was female out of the five participants. In addition, besides the telephonic method, the in-depth interviews were enhanced through social media conversations, especially WhatsApp. Along the same lines, the study used Documentary Analysis of the print and electronic media of newspapers, Rastafari music, archival documents and social media text messages. Essentially, social media analytics was used for studying texts and songs, which were gateways to understanding Rastafari responses to COVID-19 pandemic in Zimbabwe and Malawi. On ethical matters, the study uses "fire names" of some of the informants with the consent of such participants and remained anonymous where it was suitable.

\section{The hegemonic rivalries surrounding COVID-19 crisis}

The devastating effect of COVID-19 pandemic is wreaking havoc and humbling every country, economy, society, and social class such that many governments were caught unprepared or underprepared by coronavirus (Zeleza 2020). It is notable that initially China covered up on the COVID-19 outbreak and only notified WHO after hundreds had been infected. This created an environment of fear, class struggles and anxiety, which propelled 
racism and xenophobia (Nhamo et al. 2020:12). In addition, COVID-19 pandemic exposed social and political fault lines in the community with those marginalised on the receiving end. Put differently, the pervasive structural and social inscriptions of differentiation still cast their formidable and discriminatory capacities for prevention and survival including disparities on health care access. This is comparable to Sen's (1981) observation about poverty and famines where "it was not lack of food per se but the inability to access it that lay at the root of many famines". The availability of COVID-19 vaccines also had similar trends of inequitable distribution, with Africa being the most affected. This further confirms a warning against the hypocrisy of dominant powers attributed to the former Libyan leader, Muammar Gaddafi, when he stated, thus: "They will create the viruses themselves and sell you the antidotes. Thereafter, they will pretend to take time to find the solution when they already have it". This makes COVID-19 to be regarded by some Afrocentrists (Rastas included) as a planned genocide and a scandal of great magnitude.

In fact, the coronavirus was regarded as a foreign pathogen, a 'Chinese virus' in the eyes of the former American President, Donald Trump and his Republican followers (Zeleza 2020). Indeed, at the beginning of the coronavirus outbreak, China bore the brunt of both victims and victimization. The entire world feared the contagion spreading from China and other Asian countries such as South Korea, Taiwan, Singapore, and Iran where the disease quickly diffused. This triggered anti-Chinese and anti-Asian racist bashing in Europe, North America, and even Africa. Pertaining to Africa, Zeleza (2020, n.p.) notes that

For many Africans it was a source perverse relief that the coronavirus had not originated on the continent. Many wondered how Africa and Africans would have been portrayed and treated given the long history in the western and global imaginaries of pathologizing African cultures, societies, and bodies as diseased embodiments of sub-humanity.

This shows the Western hegemonic tendencies that created an imbalance in society from time immemorial.

There is a long and shameful history of unethical drug testing on communities of colour across the globe (Pailey 2020). For instance, the white "racial superiority" reared its ugly head in early 2020 when two French doctors proclaimed on their national television that Africa would be the most appropriate location for a coronavirus vaccine trial. The paradox at that time was that Africa had the lowest recorded number of cases globally (Pailey 2020). This shows that black bodies could be used or abused for the convenience of some hegemonic forces that evoked their Conradian and Hegelian racist approaches to black bodies.

The hegemonic rivalries were further noted when Tanzania and Madagascar were caught up in the COVID-19 controversies. The then Tanzanian 
President, John Magufuli, requested the military to test the genuineness of the donated COVID-19 test kits which he suspected were faulty. Furthermore, Magufuli ordered that Madagascar COVID Organics treatment be brought and used in Tanzania (Nhamo et al. 2020:13). The COVID Organics was a herbal remedy made out of Artemisia plant prepared by the Malagasy Institute of Applied Research. What is critical to note is that WHO initially dismissed the COVID Organics saying that it was not a cure for COVID-19 but later changed its position indicating the possible benefits of alternative medicines to treat the disease (Nhamo et al. 2020:13). This resonates with Nhemachena (2021:1) who observed that Africa as a region "has ever since not been allowed to reclaim anything original". Essentially, it echoes the idea that Africa and other regions of the Global South have demonstrated that they are not passive centres for medical experimentation but are sites of home-grown solutions which should be transmitted globally (Pailey 2015, 2020). Therefore, there is a lot of politics surrounding the origins, development and possible solutions to COVID-19 pandemic, which has triggered conspiracy theories, even among Rastafarians in Zimbabwe and Malawi.

\section{History of Rastafari in Zimbabwe and Malawi}

Historically, the emergence of Rastafari is traced to Jamaica among the exblack slaves partly due to the influence of Garveyism, Ethiopianism and Pan-Africanism. Marcus Garvey was an early 20th-century Jamaican black nationalist and evangelical preacher who popularised the 'Back to Africa' movement stressing black pride. As "successors of Garvey" (Tafari 1980:1), Rastafarians were told to look to Africa for the crowning of a black King who would be their Redeemer. Therefore, the coronation of Emperor Haile Selassie I on 2 November 1930 as Negus of Ethiopia was important in the history of Rastafari as it was perceived by Rastas as a fulfilment of Garvey's prophecy (Afolabi 2004; Sibanda 2012). The crowning of Selassie was a foundation to both Ethiopianism and Pan-Africanism as Rastafarians regard Ethiopia as their 'Zion' and source of inspiration.

Partly through roots reggae music popularised by Bob Marley, Rastafari spread from Jamaica to the rest of the world, including Southern African countries such as Zimbabwe and Malawi. The revolutionary element of Rastafari was anchored on black people's experiences of social, political and economic marginalisation due to colonialism. The Rastafari communities in Zimbabwe and Malawi shared a common colonial history under the British-instituted Federation of Rhodesia and Nyasaland. Under the federation, Zimbabwe was Southern Rhodesia, Zambia was Northern Rhodesia whilst Malawi was Nyasaland. Therefore, the emergence of Nyahbinghi Rastafari communities in Malawi and Zimbabwe occurred within the context of the revolutionary struggles against oppressive "Babylon" systems and the euphoria of independence (Sibanda 2019:371). 
Malawi got its independence from the British rule in 1964 under the leadership of Hastings Kamuzu Banda. The following year, His Imperial Majesty Emperor Haile Selassie I, had a three-day visit to Malawi at a time when there were ethnic wars for leadership amongst the Ngoni, Yao and Tonga (Sibanda 2019). During that visit, Haile Selassie went to Zomba, Blantyre, Chiradzulu and Cholo districts, which stimulated the growth of Rastafari movement in Malawi. It is not surprising that today, Malawi is home to thousands of Rastas of the Nyahbinghi tradition religiously following a natural livity encompassing Ital vegetarian dietary practices (Sibanda 2019:371). The legacy of Selassie's visit is notable in 'Zomba Emperor's View', a piece of land on the Zomba plateau in the Southern region of the country. The Nyahbinghi Rastafari experience in Malawi is comparable to that of Nyahbinghi Rastafari in Zimbabwe.

The emergence of Rastafari in Zimbabwe is also anchored in the revolutionary and ideological roots associated with Pan-Africanism and Ethiopianism that preceded the independence of the country in 1980 (Sibanda 2019). During the colonial period, Rastas operated as a subculture in Zimbabwe but were invigorated by the songs of freedom from roots reggae music. The euphoria of freedom from colonial rule stimulated by the historic Bob Marley show and his message at independence eve, on 17 April 1980, promoted a fresh perspective among the black populace, which further prompted the emergence of Rastafari as a significant movement in Zimbabwe. Today, Zimbabwe is home to several Nyahbinghi Rastafari houses mainly located in the urban areas (Sibanda 2019). Nyahbinghi Rastas follow an organic and vegetarian dietary pattern encompassing a wholistic natural herbalism and environmentalism as enunciated in the next section.

\section{Rastafari beliefs and practices in Malawi and Zimbabwe}

In light of the foregoing historical milestones of the development of Rastafari in Malawi and Zimbabwe, I will now provide an overview of Rastafari beliefs and practices. The Nyahbinghi Orders in Malawi and Zimbabwe recognise the divinity of Emperor Haile Selassie I, whom they regard as the head creator, black messiah, Christ in his kingly character - Jah Rastafari (Sibanda 2015a, 2017a). Rastas also believe in the Bible as a holy book from which they draw their dietary patterns, make use of ganjalmarijuana as a herb, and observe the cultivation of dreadlocks, among other teachings and practices. Indeed, Rastas believe that ganja is a natural sacred herb with multiple roles identified by Afari (2007:89) as "medicinal, nutritional, pharmaceutical, industrial, biological, cosmetological, cosmological, spiritual, intellectual and therapeutic properties for the benefit of all humanity". This shows that in light of the COVID-19 crisis, the Rastafarians do not shy away from advocating the invaluable properties of this natural sacred herb.

Rastafarians in both Malawi and Zimbabwe regard dreadlocks, a natural hairstyle, as a distinctive marker of their identity and pride in response 
to the colonial legacy that inferiorised black people. This is borne out of a Nazarene tradition and vow anchored in the Bible (cf. Lev.21:5; Num. 6.5), emulating the lion's mane (Chitando and Chitando 2004:1; Sibanda 2017a:414). In addition, Rastas follow a strict vegetarian diet that avoids ingestion of meat guided by Leviticus 11:41-42. This special diet is known as Ital (vital) food and is relevant to the Rastafari interventions in COVID-19 contexts in Malawi and Zimbabwe. Rasta music, also known as "Jah Music" encompasses roots reggae music and Nyhabinghi music vital in cascading Rastafari messages and advocacy for love, peace, justice, tolerance and harmony (Sibanda 2017a). "Jah music" is handy in propagating public health messages in the context of COVID-19 pandemic.

In line with the above, Rastas respect the symbolic colours of red, gold and green as important to their lifestyle. The colours are inspired by the Ethiopian flag, given that Ethiopia escaped colonial rule and therefore stands as an emblem of African freedom and independence. For Rastas, Ethiopia is their 'promised land' or 'Zion' and a basis for Afrocentricity. The green colour is very significant in Rastafari cosmology as it mirrors Rastafari green philosophy, vegetarian diet, growth and life (Sibanda 2015b, 2017a). These ideals are relevant to the COVID-19 crisis in Zimbabwe and Malawi, where health and being in harmony with nature are perceived through the prism of natural livity (lifestyle). The Rastafarians in Malawi and Zimbabwe make use of "dread-talk" that bastardises conventional English language, which thrives on "word, sound and power" (Afari 2007; Dolin 2001). Using dreadtalk, Rastas have stood their ground in defying the "Babylon" system and to express their agency in the face of COVID-19 crisis.

\section{Grappling with COVID-19: Rastafari perspectives and experiences}

This section explores the Rastafari perspectives, experiences and strategies they developed in response to COVID-19 crisis in Zimbabwe and Malawi. The data on the first aspect pertaining to Rastafari perspectives on the causes and interventions by the state and the international community to prevent and manage the spread of COVID-19 were gathered through indepth interviews and documentary analysis. Next, the section focuses on Rastafari experiences and strategies for responding to the COVID-19 crisis in Zimbabwe and Malawi.

\section{Rastafari perspectives on the causes of COVID-19}

The Rastafari participants in both Malawi and Zimbabwe had similar views on the causes of COVID-19 pandemic. The participants emphasised that Rastafari in general is a very diverse movement with free thinkers on the many aspects of life including the issue COVID-19 pandemic. However, the most dominant position of Rastafari communities in Malawi and Zimbabwe 
pertaining to the causes of COVID-19 pandemic is epitomised by one Rastafari Elder of Zimbabwe who was interviewed at the onset of the disease in early 2020 stating, thus:

It is not clear enough what the causes of the disease are. We are still looking for answers for its cause. However, as Rastas we are convinced that it is a man-made virus not only designed to kill but to instil prolonged fear, increasing anxiety and chaos forcing social instability, economic reconstruction resulting over a period of time. A cashless society with the majority of the world population living on credit and vouchers would emerge because without jobs and businesses people would be totally dependent on state handouts. In the new world order, the virus is used as a weapon. This is an Armageddon germ or biological warfare.

The above perspective is also shared by some Rastafarians in Malawi as testified by one of the Rastafari Elders, Ras Sakara, who belongs to the Kambalowa Binghi, Chikwawa in Southern part of Malawi. In a comparable position to that of Rastas in Zimbabwe, this Malawian Rastafari Elder upheld the view that the disease is man-made. In his words, the Elder stated, thus:

We are very worried about the fruits of Evils some minds of people produce toward other people's lives. COVID-19 pandemic and any disease that causes pain and misery in life ... anything that pains our bodies is from Evil. We regard them as Evil and Evil comes from bad minds. So COVID-19 pandemic is from evil minds and a fruit of Evil minds, but pain is not our wish.

In a follow-up interview, Ras Sakara asserted that the source of Evil was 'Babylon'. From these excerpts, it can be deduced that the Rastafari communities in Zimbabwe and Malawi regard COVID-19 pandemic as a ploy to eliminate some sections of humanity through a biological warfare. From a telephone interview with a Zimbabwean participant, Man Soul JAH, reference was made to the biblical causes of pestilence and disease after humanity errs in one way or another. For instance, Man Soul JAH said that the unbridled abuse of nature, experimentation and scientific view of the world have resulted in humanity crossing its boundary to infringe the animal kingdom, which is possibly the source of the virus. He added that although the Coronavirus disease could be natural in its cause, but it is compounded by humanity's mischievous experimentation and chicanery. Therefore, there is politricks in the entire subject on this pandemic.

In Rastafari worldview and ideology, the selfish actions of humanity can result in Armageddon, which is the earth's final battle between good and evil. Rastas believe that good will triumph in the end. Rastafarians in both Zimbabwe and Malawi asserted that JAH Rastafari never created them in order to destroy them. He will defend, protect and nourish them in time 
of sickness. Along the same lines, JAH Rastafari and Ancient elders have warned of Armageddon. History tells of past experiences from slavery and colonisation. Therefore, for Rastas, the COVID-19 pandemic is a man-made disease.

\section{Rastafari and the COVID-19 intervention strategies}

A number of precautionary and intervention strategies were implemented in response to the COVID-19 pandemic in both Zimbabwe and Malawi as will be explored below:

\section{Self quarantine and hand hygiene}

Rastafarians took measures that promoted public health guidelines. The Rastafari lifestyle was reinforced as a response to some state interventions such as lockdown rules and the guidelines for hygiene in both Zimbabwe and Malawi. Basing on a biblical text from the book of Isaiah 26:20, which says: "Come, my people, enter your inner chambers, and shut your doors behind you; hide yourselves for a while until the wrath is past" (RSV), Rastafarians reasoned that self quarantine was a divine advice. Rastas also said they practiced social distancing when in public as well as washing up to maintain hand hygiene. The participants said the issue of hygiene was part of Rastafari teaching, which stressed that cleanliness was next to Godliness. One Rasta Elder in Zimbabwe pointed that well before COVID-19, the standard Rasta greeting was a 'lion paw greeting', where clenched fists, as opposed to an open handshake, were used in a gesture that implied 'touch my blood'. This was claimed to have had an advantage of reducing the spread of communicable diseases such as typhoid and now, COVID-19 pandemic, particularly where some are transforming to an 'elbow greeting' style. These hygiene standards show that Rastas have been pacesetters despite the fact that most people in society never noticed it. Such public health practices could reposition the agency of Rastas from the margins to the centre.

In addition to the above observations, Rastas are also acting to promote public health protocols through social distancing and avoiding large gatherings to prevent the spread of the disease. Rastas in both Malawi and Zimbabwe affirmed that since COVID-19 pandemic is a contagious disease, physical (social) distancing must be practiced so as to avoid the spread of the virus. They asserted that it is better to practice the COVID-19 regulations than to die or to cause more spread of the disease. However, for Rastas, the physical (social) distancing strategy also produced its own challenges from an Afrocentric perspective. For instance, one Key Informant from Zimbabwe presented a communal position of the Nyahbinghi Rastafarians stating that

the impact of social distancing (among Rastas), first as Afrikan people, becomes disrespectful in various ways and forms. We are a very much 
hands-on and embracing people, living, eating and sleeping, just as a family. We are very communal in the way we do our daily runnings. So, the call to implement social distancing will create stress in various ways and forms.

It other words, this practice is contrary to the standard African norms and values of Ubuntu (humanness). This Rastafari Elder of Zimbabwe further noted:

The lockdown will seriously impact on the enterprising ventures of most Rastafarians because they are self-employed and the majority of them are in the informal sector. Rastas in the 21 st century argue that they are still very much discriminated against and marginalised by the state/government. On this basis, most Rastas will not register for state handouts as they perceive it to be an entrapment for manipulation by egocentric politicians.

The above views show that Rastas have not remained unscathed by the effects of the lockdown, which forced them to discontinue "Jah works" to earn a living. The statement also reveals Rastafari scepticism about state handouts, which they perceive within the framework of politricks, despite the misery associated with COVID-19 pandemic on their livity.

\section{Rastafari Ital foodways}

The study established that in both Zimbabwe and Malawi, Rastafari sought to promote health and human flouring through Ital foodways. The Ital foodways consisted of the use of natural foods and medicines in their natural diet including fresh vegetables and fruits. Authentic Rastafarians follow a strict vegetarian diet that avoids junk food and meat products. As Sibanda (2019:374) notes, Rastafarian lifestyles are confirmed by statements which say: "You are what you eat" and "Let your food be your medicine and your medicine be your food". Through right livity anchored on Ital food, Rastas could prevent and manage the impact of COVID-19 pandemic in both Malawi and Zimbabwe. As stated by Elder Ras Jahbulani Trevor Hall of Zimbabwe, "the true pure livity of the Ras Tafari is maintaining a wholistic natural herbalism, which is vegetarian and a spiritual and physically balanced life." Rastas maintain a strong nutrition and live as natural as possible through an Afrocentric culinary heritage relevant to public health interventions in COVID-19 pandemic contexts.

In addition, Ancient Abuna Bondomali and the Royal Nazarene family of Zimbabwe also echoed the importance of Ital foodways and diet in COVID-19 contexts. The Royal Nazarene family said they follow a totally vegan diet because the body should be nourished through herbs and organic diet. In fact, from narratives of Rastas in both Malawi and Zimbabwe, the Rastafari food 
consisted of vegetarian diet and alkaline food such as moringa tea, zumbani tea, artmizia tea, marijuana tea, tansy tea, neem tea, pawpaw leaf tea, ginger tea and garlic tea. All these are herbal teas that reflect food-medicines. In the face of COVID-19 pandemic, the herbal teas were much in use among Rasta families and non-Rastas alike. The researcher established through interviews and also observed that in most retail shops, the shelves sold these processed herbal teas (except for marijuana tea).

Rastafari communities in Zimbabwe and Malawi were convinced that Jah Rastafari, His Imperial Majesty, was in control as He taught them to live healthy living and follow healthy eating habits, which consist of an alkaline state of living. Given that human nutrition is put into the relationship between acids and alkalis, there is need to maintain them in proper balance of $80 \%$ alkaline and 20\% acid, thereby avoiding acid ash. As Afrika (1998:89) notes, "The normal ratio for acid-alkaline varies with the type of diet. The junk food, animal flesh eater's diet is the highest acid diet. It is the most destructive and numerous dis-eases." An alkaline state of living consists of a high content of magnesium, sodium, calcium and potassium. This is consistent with the views of Rastas in both countries whose lifestyles promote a largely vegetarian diet that would most likely keep the coronavirus at bay. Essentially, Rastas reasoned that acidic foods are a catalyst for the virus. Therefore, for Rastas, a good immune system means good health. Rastafari dietary consciousness shunned Genetically Modified Foods, which were foods artificially preserved and "polluted" by modern technologies and Western consumerism (Sibanda 2019). Elder Ras Sakara of Malawi's conclusion aptly captures this Rastafari perspective, thus:

As a remedy for COVID-19, eat natural foods. Natural foods are alkaline. They make our cells to have a conducive environment. Unnatural foods give our bodies frequencies, which denature our cells. This causes pain and early deaths than planned by the Most High, the Mighty of mighties. Remember, the Bible wrongly said that people acquired death by eating a prohibited fruit. No! But [through] eating unnatural foods, which give the bodies frequencies that do not tally with the body's nature. The nature of a thing is and must be our baseline. In everything we do, we must refer to the nature base.... In conclusion, stay natural, eat natural, drink more water - it's an alkaline.

From a list of these mitigation measures, one cannot miss the positive proactive agency of Rastafari communities in both Malawi and Zimbabwe, through Ital foodways under the shadow of COVID-19 pandemic.

\section{Rastafari herbal remedies}

In both Zimbabwe and Malawi, Rastafarians stressed the importance of indigenous natural herbs as a strong measure to promote human flourishing. 
The vitality of herbal healing in the context of the COVID-19 pandemic was strongly affirmed by one Rastafari Elder who stated: "Life is in herbs because herbs give strength and natural healing." Top on the list of herbs used by Rastas is marijuana/ganja/cannabis, which is a miracle plant to enhance health and well-being. This resonates with the Rastafari belief in the supremacy of life, partly reflected in the life-affirming values of marijuana. Informed by the Bible, Rastas in both Malawi and Zimbabwe have the conviction that marijuana is the tree of life for the healing of the nations (Revelation 22:2). This resonates with Hewitt's (2018) observation that among Rastafarians this 'holy herb' (marijuana), is a free gift from God ushered through God's creation. Therefore, the Rastafari use of indigenous herbs (including marijuana) is critical, against the backdrop of challenges facing bio-medicine in the context of COVID-19 pandemic in Malawi and Zimbabwe.

Basing on my previous studies on Rastafari communities in the preCOVID-19 era, the use of marijuana/ganja/cannabis for therapeutic effects are extant, where members of this movement called for its legalisation (Sibanda 2014). In the current study the Key Informants in Zimbabwe and Malawi further confirmed the medicinal and herbal therapeutic effects of cannabis in the context of COVID-19. The informants were unanimous at claiming that Cannabis Sativa has compounds like THC and CBD, which can be used to treat various symptoms, including those associated with the coronavirus. Apparently, this claim has a contemporary scientific basis as research into 'medicinal marijuana' are becoming prevalent and popular because of their health benefits, encompassing pain relief, improved anxiety, and reduced inflammation (Simpson 2021). In other words, cannabis products have extensive therapeutic benefits, which may offer help in the fight against COVID-19, a disease associated with severe acute respiratory distress and lung fibrosis. This shows that Rastafari is a positive force in the quest for health and healing in response to COVID-19 pandemic, though this sometimes goes unnoticed by the larger populace.

The study also established that Rastas in Malawi and Zimbabwe upheld the need to steam and bath with various indigenous herbs such as zumbani and marijuana as a precautionary measure or for managing the dis-eased, on a regular basis. The herbs clear the bronchitis and breathing system. Therefore, for Rastafarians, steaming and bathing could keep the coronavirus at bay because of the high temperatures and the herbal therapy. On the use of marijuana, the mainstream view is that the consumption of cannabis is most commonly done by inhaling the smoke of cannabis flower (Simpson 2021). However, this is not the only way cannabis's therapeutic compounds can be utilised. For instance, alongside using it in bathing and steaming, cannabis oil extracts, like CBD oil, also come to the fore, among other uses. As Simpson (2021:n.p.) notes, "Cannabis oil can be consumed through ingestion, vaping, nasal sprays, or topical application. Many delivery mechanisms don't involve the lungs and leave out potentially harmful substances 
that come with smoke inhalation." This observation shows that there is a lot of potential in the use of cannabis in the fight against COVID-19 pandemic, among Rastafarians.

\section{Chi Gong: the call for regular physical exercise}

Besides surviving on a healthy lifestyle characterised by Ital food and diet, Rastas in Malawi and Zimbabwe expressed the need to do physical exercises regularly. This is a promotion of human flourishing through art therapy comprising "meditation, physical work (Jah works) and exercise" (Sibanda 2019:378). These exercises are based on the 'Chi Gong' bodily movement, which is a physiotherapy and yoga philosophy traceable to Kermetic knowledge. Literally, "Chi" is control of breath, whilst "Gong" means "master" (Sibanda 2019). For Rastafarians, 'Chi Gong' is meant to cleanse, heal and energise the body. The ability to control ones breath through 'Chi Gong' physiotherapy is relevant in addressing COVID-19 pandemic, an acute respiratory distress syndrome. Building up on this, Elder Ras Sakara of Malawi, who has mastered the art of 'Chi Gong', stated:

Apart from eating natural food-medicines [as remedy for COVID-19], we must do physical exercises. These exercises open the 12 gates in our body to be filled up with enough Ang Els (airs) like oxygen, hydrogen, among others, which sustain our life....Have rest and relax. Walk on earth barefoot in the sunlight to receive and be charged with their frequencies. Our melanin convert those frequencies into into energy, which fight body disorders.

The skills and philosophy of 'Chi Gong' show that Rastafarians are Afrocentric. They are prepared to heal themselves through this art of physiotherapy that thrives on the individual's effort. This confirms the Rastafari view that health is not injected but earned. For Rastas, 'Chi Gong' is helpful for the health and well-being of people under COVID-19 crisis in both Malawi and Zimbabwe.

\section{Rastafari environmentalism and COVID-19}

Rastafari communities are super environmentalists informed by an I-consciousness and Rastafari 'green philosophy' that is in harmony with nature (Sibanda 2015, 2019). In this way, the Rastas in Malawi and Zimbabwe are convinced that the global trend of lockdown and quarantine have made the global environment to reset and improve its health. In the words of one Key Informant: "The rivers, oceans, lakes are getting strength from no pollution of pollutants due to the fact that industries are on lockdown. Even the air is getting more fresh because aeroplanes are not flying. The climate is 
on reset!" There is a critical need for a balance of things in the created order. One Key Informant from Malawi stated:

Because of the climate change crisis, viruses that were dormant erupted and proliferated. Mother Earth is saying I have had enough pollution of carbon emissions that is depleting the Ozone layer and the world came to a stand still through lockdown. For two months Mother Earth had a well deserved sigh under the new normal. COVID-19 is a new strain that could be linked to environmental changes.

Thus, an environmental stewardship is called for to abate the current trends of the Anthropocene whose causes are linked to anthropogenic factors of the most industrialised nations. A Zimbabwean Elder echoed these sentiments saying:

All what is going on is interrelated, the Coronavirus is said to thrive during cold climate. And now wreaking havoc in all nations. The virus is climate related. Humanity is shooting itself in the foot. The erratic change we have in our climactic cycle isn't normal and in many instances looking as if it's being controlled by man (the order) for their own benefits, but with detrimental effects to the environment.

This reminds us that in the face of COVID-19 pandemic, Rastafarians remained conscious to live a purposeful life where the environment/Mother Earth are protected. A Zimbabwean Rastafari Elder, Ras Jahbulani, added his voice by stating, thus:

It is important to strike a balance between humanity and nature. [As human beings] no other strategy is needed than to maintain a unified thinking embracing our diversity and practice of One Love, One People, One human race. Jah Ras Tafari!

With Just One Earth, collective consciousness is required to attack the 'elephant in the room' - COVID-19 pandemic. From the Malawian perspective, Elder Ras Sakara said: "Plant more trees and herbs, which purify air that make our environment more habitable." This echoes the advice from His Imperial Majesty that Rastas must plant a million trees every year (Sibanda 2012, 2015), the planting of which is crucial to provide food-medicines and fresh air for promoting human flourishing.

\section{Coping with COVID-19 crisis through reggae music}

The study established that in both Zimbabwe and Malawi Rastafari communities utilise 'Jah music', that is, roots reggae music and Nyahbinghi music in two main ways: (a) to promote public health messages in response to the COVID-19 pandemic (b) as a tool to warn people about 'conspirational 
thinking' and bio-medical warfare manifesting in the form of COVID-19 pandemic. The messages that come through music make Rastafari a significant social force in society.

\section{Promotion of public health messages}

In the two countries under focus, COVID-19 awareness campaigns through music were done. For instance, on the first point, I refer to one of the songs on COVID-19 by a group of Zimbabwean Rastafari artistes: Toggyman, Mama Ithiopia and Ancient Abuna Bondomali who collaborated on an awareness campaign song. In the collaboration, Toggyman was on the lead vocals whilst Mama Ithiopia featured on the backing vocals and Ancient Abuna Bondomali did the poetry. The message was that COVID-19 was a very dangerous disease. Music becomes a handy tool, thriving as 'word, sound, power'. It shows the power of oral art where the musicians sing about, inter alia, "misery in people and people in misery" (Muwati 2018:xiv). In the context of COVID-19, 'Jah music', particularly reggae music, provided "a mode of reasoning that offers an alternative to the established way of doing and looking at things" (Karenga 1993:7). Therefore, playing and listening to reggae music is a coping strategy that Rastas use in their interventions. Reggae music has the potential to endear Rastafarians to people of all walks of life since its popularisation by Jamaican Rastafari reggae icons such as Bob Marley and the Wailers. In the context of COVID-19, Rastafarians could easily occupy the centre from their usual social location at the margins in both Zimbabwe and Malawi thereby confirming Lucky Dube's observation that "Nobody can stop reggae "cause reggae is strong" (1989). Reggae music enhances Rastafari resilience as a minority and marginalised religion in the face of global challenges like COVID-19 pandemic.

\section{'Conspirational thinking', bio-medical warfare \& vaccination apathy}

On this second point, we find the ambivalence of Rastafari contribution to issues of public health and development in the context of COVID-19 crisis. The Rastafarian communities in both Zimbabwe and Malawi expressed their open reservations about the safety of vaccines to prevent the spread of COVID-19 pandemic. In fact, Rastas have no trust in the whole inoculation exercise. For Rastas, the inoculation programme is a Western ploy to wipe out the Black race. Therefore, resistance to vaccination efforts by Rastas is due to the fact that historically, previous epidemics saw black people being used as guinea pigs both on the African continent and in the West. From existing literature, some French doctors suggested that COVID-19 vaccines needed to be tested on the African continent (Pailey 2020). The Social Media was also awash with stories that claimed that the mortality rate of the vaccinated people out-weighed the non-vaccinated (Wolfe \& Nierenberg 2021). This has created a 'vaccination hesitancy' and conspiration theories globally, thereby entrenching Rastafari scepticism in both Zimbabwe and Malawi. 
In line with the above, Elder Ras Jahbulani Trevor Hall used music to warn fellow Rastas about the sinister plans of 'Babylon' pertaining to biological warfare. He produced two songs related to these issues, namely, 'Third world war inna Afrika' and 'It's a Conspiracy'. In his words, Elder Ras Jahbulani stated: "My 2 songs I had written and recorded a couple of years ago warning people of the conspiracy and the third world war, are being confirmed since we're in the midst of that right now." Commenting on the relevance of the message in his songs, Elder Ras Jahbulani Trevor Hall added that:

Most Ras Tafari sons and dawtas I know see the COVID-19 pandemic as part of the planned genocide by the new world order to eliminate a large portion of the world population during this 4th Industrial Revolution (the Armageddon), which has been part of their long term plan as seen in the way they had constructed the collection of books to create their bibliography scriptures called the King James Version of the Holy Bible. This started their spiritual subduance of mostly our Black Afrikan people and people of colour.

In this way, it is this type of ideological struggles that keep people immobilised in the context of vaccination programme in COVID-19 pandemic times. To further hammer this Rastafarian view on vaccination, Elder Ras Jahbulani added:

It's not just the Ras Tafari community asking these questions about COVID-19. The conspiracy is now a harsher reality. How and why in your right mind would you be willing to take vaccination if your livity is pure and there's no proof it's preventative or a cure to the disease?

This is a similar position held by Rastas in Malawi as confirmed by an Empress from that country who expressed it through a Reggae song chanting down the 'Bumbo Klaat' in COVID-19 contexts. This Rastafari stance may be mistaken by mainstream society not only to be anti-society and countercultural, but also extreme, unreasonable and counter productive. The Rastafarians in Zimbabwe and Malawi risk being regarded as a movement minimising the threat of COVID-19 pandemic.

\section{Conclusion}

At the beginning of this chapter, I made reference to Adichie's concern over the dangers of a single story. The common single narrative is to regard the dominant and more established religions such as Islam and Christianity as the only key development agents that most African governments could work with in the fight against COVID-19 pandemic. In this way, minority religions such as Rastafari are excluded at the discussion platforms for policy 
formulation on, inter alia, health and other development initiatives. As the chapter has demonstrated, the Rastafari communities in Zimbabwe and Malawi are a force to reckon with in the quest for health and well-being in response to COVID-19 and the development agenda through their cultural identities. Indeed, Rastafari cultural identities such as music, Ital foodways, holistic natural herbalism and environmentalism as well as spiritual and physically balanced lives engender creative and unique parameters that promote public health and human flourishing in both Zimbabwe and Malawi. Through a labour of love and resistance not to die in the face of COVID-19 (Calvo 2020), Rastafarians are defying the western approaches to health and healing enmeshed in hypocrisy and politricks.

The chapter further demonstrates the "danger of a single threat" (Redfield 2020) where COVID-19 pandemic eclipses all other threats, in both Zimbabwe and Malawi. Through 'conspirational thinking', Rastafarians defy Western epistemological hegemonic tendencies and biomedical warfare approaches thereby concentrating the cause of their misery around a singular threat - the politricks of Babylon system. In this way, despite being a significant social force, the Rastafarian total resistance to Western biomedical technology (including COVID-19 vaccines), influenced by an Afro-epistemological standpoint, is tantamount to counter-productivity, once "stupid deaths" (Paul Farmer's phrase cited in Redfield 2020) begin to be recorded among their rank and file. Yet, against the backdrop of a lingering medical imperialism, Rastafarians need to reposition their agency by exercising a judicious integration of Afrocentric knowledge systems and strategies with any progressive Western-engineered biotechnology. This is especially critical given that Rastafari foregrounds the embracement of human diversity and the practice of One love, One aim, One people and One human race in order to drive positive complementary actions in the face of pandemics in Malawi and Zimbabwe.

\section{References}

Adichie, C.N. (2009) “The Danger of a Single Story”, TED Global, Retrieved from https://www.ted.com/talks/chimamanda_ngozi_adichie_the_danger_of_a_single_story?language=en, Accessed: 20 July 2020.

Afari, Y. (2007) Overstanding Rastafari: Jamaica's Gift to the World, Jamaica: Senya Cum.

Afolabi, J.A. (2004) "By the Rivers of Babylon: The Bondage Motif in the Performing Arts, Life and Aesthetics of Rastafarians" Tinabantu: Journal of African National Affairs, 2(1): 37-49.

Afrika, L.O. (1998) Afrikan Holistic Health: Your Guide to Health and Well-Being, Brooklyn, NY: A\&B Publishers Group.

Asante, M.K. (1998) The Afrocentric Idea, Philadelphia, PA: Temple University Press.

Asante, M.K. (2007) An Afrocentric Manifesto: Toward an African Renaissance, Malden: Polity. 
Calvo, D. (2020) “'They Agreed To Kill Us, We Agreed Not To Die': Acts of Love and Resistance to Confront Covid-19 by Members of Afro-Brazilian Religions" https://anthrocovid.com/2020/06/05/they-agreed-to-kill-us-we-agreed-not-to-die-acts-of-love-and-resistance-to-confront-covid-19-by-members-of-afrobrazilian-religions/, Accessed: 20 July 2020.

Chitando, E. and Chitando, A. (2004) "Black Female Identities in Harare: The Case of Young Women with Dreadlocks" Zambezia, 31 (1\&2): 1-21.

Cox, J.L. (1996) Expressing the Sacred: An Introduction to the Phenomenology of Religion, Harare: University of Zimbabwe Press.

Dolin, K.Q. (2001) "Words, Sounds and Power in Jamaican Rastafari" MACLAS Latin American Essays, Retrieved from https://www.questia.com/library, Accessed: 28 May 2020.

Dube, L. (1989) "Reggae Strong" from Album Prisoner, Produced by Shanachie Label, https://www.dancehallreggaeworld.com/lucky-dube.html

Edmonds, E.B. (2003) Rastafari: From Outcasts to Culture Bearers, Oxford: Oxford University Press.

Hewitt, R.R. (2018) "For the Healing of the Nations: Rastafari Dialogical Narrative Discourse on the Decriminalization of Marijuana/Ganja" in Okyere-Manu, B. and Moyo, H. (Eds). Intersecting African Indigenous Knowledge Systems and Western Knowledge Systems: Moral Convergence and Divergence, Pietermaritzburg: Cluster Publications, 116-134.

Johnson, V.D. (2001) "The Nguzo Saba as Foundation for African American College Student Development Theory” Journal of Black Studies, 31(4): 406-422.

Karenga, M. (1993) Introduction to Black Studies, Los Angeles: University of Sankore Press.

Kovalchuk, A., Wang, B., Li, D., Rodriguez-Juarez, R., Ilnytskyy, S., Kovalchuk, I., \& Kovalchuk, O. (2021) "Fighting the Storm: Could Novel Anti-TNF $\alpha$ and anti-IL-6 C. sativa cultivars tame cytokine storm in COVID-19?" Aging, 13(2):1571-1590.doi:10.18632/aging.202500.

Muwati, I. (2018) "Introduction: Singing Nation: Music and Politics in the Decade of Crisis" in I. Muwati, T. Charamba and C. Tembo (Eds). Singing Nation and Politics: Music and the 'Decade of Crisis' in Zimbabwe 2000-2010, Gweru: Midlands State University Press.

Nhamo, G., Dube, K., \& Chikodzi, D. (2020) Counting the Cost of COVID-19 on the Global Tourism Industry, Cham, Switzerland: Springer Nature Switzerland AG.

Pailey, R.N. (2020) "Africa does not need saving during this pandemic", Al Jazeera, 13 April 2020, Retrieved from https://www.aljazeera.com/indepth/opinion/africasaving-pandemic-200408180254152.html, Accessed 5 June 2021.

Pailey, R.N. (2015) “Treating Africans with an Untested Ebola Drug” Retrieved from https://www.alijazeera.com/indepth/opinion/2014/12/treating-africanswith-an-unte-2014123195838317148.html, Accessed: 20 August 2020.

Redfield, P. (2020) "COVID-19: The Danger of a Single Threat" Retrieved fromhttps://culanth.org/fieldsights/the-danger-of-a-single-threat, Accessed: 20 July 2020.

Sen, A. (1981) Poverty and Famines: An Essay on Entitlement and Deprivation, Oxford: Clarendon Press.

Sibanda, F. (2019) "Promoting Human Flourishing through Rastafari Ital Foodways in Africa" in M.C. Green (Ed). Law, Religion and Human Flourishing in Africa, Stellenbosch: AFRICA SUN MeDIA, 363-381. 
Sibanda, F. (2017a) "Praying for Rain?: A Rastafari Perspective from Zimbabwe" The Ecumenical Review, 69(3): 411-424.

Sibanda (2017b) "Rastafari Perspectives on Land Use and Management in Postcolonial Zimbabwe” in M.C. Green, R.I.J. Hackett, L. Hansen and F. Venter (Eds). Religious Pluralism, Heritage and Social development in Africa, Stellenbosch: SUN MeDIA Stellenbosch, 189-203.

Sibanda, F. (2015a) “'Legalize it!': Re-thinking Rastafari-State Relations in Postcolonial Zimbabwe", in Pieter Coertzen, M.C. Green \& L. Hansen (Eds). Law and Religion in Africa: The Quest for the Common Good in Pluralistic Societies, Stellenbosch: SUN MeDIA Stellenbosch, 185-204.

Sibanda, F. (2015b) "Rastafari Green Philosophy for Sustainable Development in Postcolonial Zimbabwe: Harnessing Eco-theology and Eco-justice" in F.H. Chimhanda, V.M.S. Molobi \& I.D. Mothoagae (Eds). African Theological Reflections: Critical Voices on Liberation, Leadership, Gender and Eco-justice, UNISA: Research Institute for Theology and Religion, 187-206.

Sibanda, F. (2014) "Quest for Identity: Rastafari Cultural Identities as Expression of Liberation in Postcolonial Zimbabwe" Unpublished Doctor of Philosophy Thesis submitted to the Department of Religious Studies, Classics and Philosophy, Harare: University of Zimbabwe.

Sibanda, F. (2012) "The Impact of Rastafari Ecological Ethic in Zimbabwe: A Contemporary Discourse" The Journal of Pan African Studies, 5(3): 59-76.

Simpson, K.W. (2021) "Cannabis as a treatment for COVID-19" Retrieved from https://www.openaccessgovernment.org/cannabis-as-a-treatment-forcovid-19/106833/, Accessed: 7 July 2021.

Tafari, I.J. (1980) "The Rastafari - Successors of Marcus Garvey” Caribbean Quarterly, 26 (4): 1-12.

WHO. (2020) Coronavirus disease 2019 (COVID-19) Situation Report - 51. Retrieved from https://www.who.int/docs/default-source/coronavirus/situationreports/20200225-sitrep-36-covid-19.pdf?sfvrsn=2791b4e0_2. Accessed 20 August 2020.

Wolfe, J. \& Nierenberg, A. (2021) “The Delta Misinformation Loop”, The New York Times, August 10.

Zeleza,P.T.(2020) "The Coronavirus: The PoliticalEconomy of a Pathogen" Retrieved from https://www.linkedin.com/pulse/coronavirus-political-economy-pathogenpaul-tiyambe-zeleza/?trackingId=fr9iQ29QSr2Ui9M57n7VWA\%3D\%3D, Accessed: 25 March 2020. 